\title{
Convergent Validity of Zulliger-CS with the Social Skills Inventory for the Elderly $^{1}$
}

\author{
Jucelaine Bier Di Domenico Grazziotin², Silvana Alba Scortegagna² \\ ${ }^{2}$ Universidade de Passo Fundo, Passo Fundo-RS, Brazil
}

\begin{abstract}
Psychological evaluation instruments need to demonstrate their usefulness to respond to social problems and according to the reality of people. This study aimed to find evidence of convergent validity of the interpersonal relationship indicators and the cognitive triad of the Zulliger in the Comprehensive System (ZSC) with the Social Skills Inventory for the Elderly (IHSI Del-Prette). The sample consisted of 78 elderly individuals, between 60 and 96 years old $(M=76.07)$. As instruments, the sociodemographic and health characterization protocol was used, the Mental State Mini-Exam, the ZSC and the IHSI-Del-Prette. Pearson's correlation showed significant associations of the variables of the interpersonal relationship (PER), contents (Cg, A\%) and cognitive triad (R, D, XA\%, S-, X+\%) of the ZSC, with the general score G and the IHSI Del-Prette factors F4, F2, F3 and F1. The results show the convergent validity of ZSC with IHSI Del-Prette.
\end{abstract}

Keywords: Zulliger test, psychological tests, test validity, cognitive processes, interpersonal relations

\section{Validade Convergente do Zulliger-SC com o Inventário de Habilidades Sociais para Idosos}

\begin{abstract}
Resumo: Instrumentos de avaliação psicológica precisam demonstrar sua utilidade para responder aos problemas sociais e de acordo com a realidade das pessoas. Este estudo objetivou buscar evidências de validade convergente dos indicadores do relacionamento interpessoal e da tríade cognitiva do Zulliger no Sistema Compreensivo (ZSC) com o Inventário de Habilidades Sociais para Idosos (IHSI Del-Prette). A amostra constituiu-se de 78 idosos, entre 60 e 96 anos $(M=76.07)$. Como instrumentos utilizaram-se o protocolo de caracterização sociodemográfica e de saúde, o Mini-Exame do Estado Mental, o ZSC e o IHSI-Del-Prette. A correlação de Pearson mostrou associações significativas das variáveis do relacionamento interpessoal (PER), de conteúdos $(\mathrm{Cg}, \mathrm{A} \%)$ e da tríade cognitiva (R, D, XA\%, S-, X+\%) do ZSC, com o escore geral G e os fatores F4, F2, F3 e F1 do IHSI Del-Prette. Os resultados evidenciam a validade convergente do ZSC com IHSI Del-Prette.
\end{abstract}

Palavras-chave: teste de Zulliger, testes psicológicos, validade do teste, processos cognitivos, relações interpessoais

\section{Validez Convergente del Zulliger-SC con el Inventario de Habilidades Sociales para ancianos}

\begin{abstract}
Resumen: Los instrumentos de evaluación psicológica deben demostrar su utilidad para responder a los problemas sociales y de acuerdo con la realidad de las personas. Este estudio objetivó buscar evidencias de validez convergente de los indicadores de la relación interpersonal y de la tríada cognitiva del Zulliger en el Sistema Comprensivo (ZSC) con el Inventario de Habilidades Sociales para los ancianos (IHSI Del-Prette). La muestra se constituyó de 78 ancianos, entre 60 y 96 años $(M=76.07)$. Como instrumentos se utilizaron el protocolo de caracterización sociodemográfica y de salud, el Mini-Examen del Estado Mental, el ZSC y el IHSI-DelPrette. La correlación de Pearson mostró asociaciones significativas de las variables de la relación interpersonal (PER), de contenidos (Cg, A\%) y de la tríada cognitiva (R, D, XA\%, S-, X +\%) del ZSC, con el puntaje general G y los factores F4, F2, F3 y F1 del IHSI Del-Prette. Los resultados evidencian la validez convergente del ZSC con IHSI Del-Prette.
\end{abstract}

Palabras clave: test de Zulliger, tests psicológicos, validación del test, procesos cognitivos, relaciones interpersonales

\footnotetext{
'Support: Article derived from the master's dissertation of the first author under the supervision of the second, defended in 2015, in the Postgraduate Program in Human Aging of the Universidade de Passo Fundo.

Correspondence address: Jucelaine Bier Di Domenico Grazziotin. Universidade de Passo Fundo. Faculdade de Educação Física e Fisioterapia. Bairro São José, BR 285, Passo Fundo-RS, Brazil. CEP 99.052-900. E-mail: jucelainegraz@terra.com.br
}

Psychological assessment instruments are of paramount importance in interpreting the psychological characteristics of people, but the legitimacy of the information depends on empirical research that certifies its psychometric properties. There are several ways to obtain evidence of validity of a test, among them the convergent validity understood as an association between two instruments that proposes 
to evaluate the same construct (American Educational Research Association [AERA], American Psychological Association [APA], \& Nacional Council on Measurement in Education [NCME], 2014). Some Brazilian studies have sought evidence of validity with the use of Zulliger in the Comprehensive System (ZSC).

Grazziotin and Scortegagna $(2012,2013)$ performed two correlation studies of the ZSC focusing on the relationship and productivity variables, with the Social Skills Inventory (Portuguese acronym: IHS). The study included 19 people in the first study and 40 in the second, aged between 18 and 43 years. In the results, significant correlations $(p<0.05)$ occurred, participants who demonstrated a positive representation of themselves and others in an accurate manner (GHR), exhibited more elaborate social skills (GIHS); those who presented better relations (GPHR, Pure H) showed greater social skill (F3); those who expressed increased interest and concern with people signaled more assertiveness (F1IHS) and; those that showed more conflicted relationships (PHR) had less self-control of aggressiveness (F5).

Tavella and Villemor-Amaral (2014) investigated whether ZSC cognitive and affective indicators correlated with the Test of Figural Creativity for Children (TFCC) in 90 children aged 11 and 12 years. The group of more creative children presented greater capacity of mental productivity and less conventionality demonstrated by the significant increase in the variables R, M and FQ- of the ZSC.

With the inclusion of the elderly, Franco and Villemor Amaral (2009) investigated the convergent validity between ZSC and Pfister, with 223 individuals between 19 and 83 years of age. The qualitative analysis showed complementarity between the techniques in understanding non-externalized feelings of anguish, oppositional reactions and cognitive resources of participants.

Two recent studies investigated the validity of ZSC in the evaluation of elderly people with chronic diseases. Rien, Scortegagna, Grazziotin and Bertolin (2017) evaluated 61 elderly people, between 60 and 90 years of age, 30 with Parkinson's disease and 31 free of the disease, focusing on self-perception and interpersonal relations. The elderly with Parkinson's disease presented negative self-criticism, feelings of devaluation and dependence, greater reserve and distrust in interpersonal relations, and less use of authoritarian defenses, demonstrated by the significant increase in variables $\mathrm{Hd}$, MOR, Sum V, Fd and lowering in PER. There was a positive association between $\mathrm{ZSC}$ variables and age, income, disease severity, and negative association with time of diagnosis.

Gregoleti and Scortegagna (2017) sought evidence of ZSC validity to assess cognitive aspects and interpersonal relationships of 60 elderly people, aged 65 years and over, 30 of whom had chronic kidney disease and 30 were free of the disease. The elderly with chronic kidney disease presented lower productivity, tendency to cognitive distortions (R, $\mathrm{X}-\%)$ and difficulty in interpersonal relationships (PHR $>$ GHR). The related studies with chronic diseases and elderly ratified the relevance of the ZSC to respond to the proposed objectives.
Two other studies, with the use of other ink stain instruments that bear similarities to Zulliger in both application and interpretation, were performed with elderly subjects at the international level. The first study by Pertchik, Shaffer, Erdberg and Margolin (2007) investigated the personality dynamics of 54 elderly, 60-80 years old, non-patients, with Rorschach, Comprehensive System. The older elderly presented defensive behaviors, seeking protection of selfesteem (PER) and need for unsatisfied contact (T). The second study, conducted by Meyer, Giromini, Viglione, Reese and Mihura (2015) examined the association between education, age, ethnicity and gender, with Rorschach Performance Assessment System (R-PAS) variables using three clinical and non-clinical samples, including youth, adults and a limited number of elderlies. In the clinical sample of youngsters, the increase in age was mainly associated with more conventional perception and less processing of logical thinking.

As can be observed, studies of evidence of ZSC validity with the elderly are scarce, which is also portrayed in the literature (Grazziotin \& Scortegagna, 2016). The longevity of populations worldwide and notably in Brazil is an achievement that encompasses factors such as well-being and health (World Health Organization [WHO], 2015) and may be accompanied by opportunities (trips, professional career, social interaction) (Scheibe And Carfensen, 2010, WHO, 2015), learning and exchange of experiences (Charles, 2005; Cully, LaVoie, \& Gfeller, 2001), which motivates the increase of validity studies of instruments that focus on the constructs cognition, interpersonal relationship and social skills, to support the practice of psychological assessment in the better understanding of the elderly.

Cognitive processes refer to how people think about their experiences, adapting best when they can think coherently, logically, and flexibly. Interpersonal relationships, on the other hand, imply the degree of interaction and social isolation, in cooperation and aggressiveness, if one maintains a level of interest and intimacy for others, and perceives others and social situations empathically (Weiner, 2003).

Social skills (SS) imply the ability of the individual to organize thoughts, feelings, actions, and the balance of interpersonal relationships (assertiveness, affectivity, communication, aggressiveness and sexuality) (Del Prette \& Del Prette, 2001). Adolescents and adults with higher scores in SS have less conflicted interpersonal relationships, higher academic and work performance (Feitosa, Del Prette, \& Del Prette, 2012; Grazziotin \& Scortegagna, 2012, 2013), higher social well-being and social interaction, lower social anxiety (Bolsoni-Silva \& Loureiro, 2014; Pinto, Barham, \& Del Prette, 2016).

Another instrument that is being studied for use with the elderly is the Social Skills Inventory, version for the elderly (IHSI-Del Prette). Historically, studies that sought to analyze the psychometric properties of the instrument date from 1998 to 2000, and for use with young adults aged 18 to 25 years in 2001 (Del Prette \& Del Prette, 2013). Other studies have sought to broaden age ranges and reference standards, including the version for the elderly (Braz, Cômodo, 
Del Prette, Del Prette, \& Fontaine, 2013; Braz, Del Prette, \& Del Prette, 2011; Carneiro, Falcone, Clark, Del Prette, \& Del Prette, 2007), with factorial analyzes for this population (Braz, 2013).

Braz et al. (2011) evaluated the effects of a training program on assertive SS with 15 elderly, aged 60 and over, divided into two groups. An experimental group consisting of seven women and one man and a control group consisting of six women and one man. The results of the IHSI-Del Prette, adapted for the elderly (Carneiro et al., 2007) indicated significant differences between the pre-test and the post-test, with an increase in the overall SS score and increase of the assertiveness in the experimental group.

In the sequence, Braz et al. (2013) conducted two studies with the objective of investigating the correlation between the repertoire of SS among elderly parents and adult children, and the influence of the quality of the relation between them in the repertoire of these skills. The first study evaluated 142 dyads, adult parents and adolescent children; the second investigated the relationship between 77 elderly parents and 107 adult children. The results of IHSA - Del-Prette, o IHS - Del-Prette, IHSI (Portuguese acronyms) adapted for the elderly (Carneiro et al., 2007) showed similarities for 29 of the $38 \mathrm{SS}$.

Although there are inherent differences between the instruments of psychological assessment (Dao, Prevatt, $\&$ Horne, 2008), the use of different methods can provide a global view to answer the problem investigated and bring increment to the interpretations (Dao et al., 2008; Mihura, 2012). Considering the above, this study aimed to find evidences of convergent validity of the interpersonal relationship indicators and the Zulliger cognitive triad in the Comprehensive System (ZSC) with the Social Skills Inventory for the Elderly (IHSI Del-Prette).

The consolidation of this objective, points to the hypothesis that the more adjusted the people in their relationships and in the cognitive scope, the greater their SS repertoire. Based on this assumption, the ZSC variables that can report on interpersonal and cognitive adjustment $(\mathrm{H}, \mathrm{Sum} \mathrm{H}[(\mathrm{H})]$, GHR, COP, R, D, W, $\mathrm{M}, \mathrm{X}+\%, \mathrm{XA} \%, \mathrm{DQ}+, \mathrm{Zf}, \mathrm{P}, \mathrm{a}, \mathrm{Cg}$ ) may correlate significantly and positively with the general IHSI scores: $G$ and F1, F2, $\mathrm{F} 3$, and F4. The variables of the ZSC that suggest limitation in the interpersonal and cognitive relationship (Hd, [(Hd)], PHR, Sum T, Fd, AG, isolation, $\mathrm{A} \%$, An, Dd, $\mathrm{X}-\%, \mathrm{Xu} \%$, $\mathrm{S}-\% \mathrm{M}, 2 \mathrm{AB}+($ Art + Ay), p, PSV, DQv, MOR, Sum6, WSum6) may be significantly and negatively correlated with the IHSI general score G and F1, F2, F3 and F4. The PER variable can correlate significantly and positively with the $\mathrm{F} 4$ and, negatively with the general score $\mathrm{G}$ and F1, F2, F3 of the IHSI.

\section{Method}

\section{Participants}

A total of 78 healthy subjects, aged between 60 and 96 years $(M=76.07, S D=4.58), 39$ males $(50 \%)$ and
39 females (50\%), with a mean educational level of 6 $(S D=4.01)$, belonging to the low socioeconomic class, $\mathrm{C} 1$ $(54 \%)$ and B2 (26\%), coming from institutions that offer coexistence groups in the State of Rio Grande do Sul. As a criterion of exclusion, the following were considered: (a) history of psychiatric treatment, stressful situations resulting from the diagnosis of illness or physical disability, in the last six months; (b) a history of any major loss that has caused suffering in the last six months; (c) cognitive, hearing and visual impairment that interfered with the performance of the tests. These data were obtained through the sociodemographic and health characterization protocol, and the Mini-Mental State Examination (MMSE).

\section{Instruments}

Sociodemographic and health characterization protocol with the objective of verifying the inclusion or exclusion criteria of the sample. Composed of questions about age, gender, marital status, schooling, professional or occupation, family and health conditions. The socioeconomic classification (CEBB) was based on the Socio-Economic Survey / 2012 - IBOPE (Associação Brasileira de Empresas de Pesquisa, 2012).

Mini-Mental State Examination (MSME) (Folstein, Folstein, \& McHugh, 1975) translated and validated in Brazil by Bertolucci, Brucki, Campacci and Juliano (1994), evaluates cognitive aspects. To meet the criteria of inclusion and exclusion of the sample, the cut-off point of 26 points was used (Brucki, Nitrini, Caramelli, Bertolucci, \& Okamoto, 2003).

Zulliger in the Comprehensive System (ZSC) - individual form (Villemor-Amaral \& Primi, 2012) - consists of a set of three cards, with little structured ink stain, that make possible to understand the psychic functioning of the individual. Brazilian standards for the test were obtained with 475 adults between 18 and 83 years old (Franco, Cardoso, VillemorAmaral, \& Primi, 2012).

For the present study we considered 13 variables of the ZSC that compose the relationship grouping: human whole content $(\mathrm{H})$, sum of $H($ Sum $H)$, whole para-human $[(\mathrm{H})]$, human detail $(\mathrm{Hd})$, para-human detail $[(\mathrm{Hd})]$, good human representation (GHR), poor human representation (PHR), cooperative movement (COP), shading-texture (Sum T), food or eating action (Fd), personalized answers (PER), aggressive movement (AG), and isolation. Answers of animal content $(\mathrm{A} \%)$, clothing $(\mathrm{Cg})$ and anatomy $(\mathrm{An})$ have been included that can enrich the understanding of mental functioning and, therefore, help the understanding of interpersonal relations. The related variables are listed in the hypothesis of this study and are presented in Table 1.

In addition to the relationship grouping, we considered 23 variables that make up the cognitive triad, related to processing, mediation and ideation. To know: number of answer (R), detail answer (D), unusual detail (Dd), whole answer (W), answer synthesized (DQ +), organizational activity (Zf), human movement (M), 
conventional shape $(\mathrm{X}+\%)$, appropriate shape with minimum distortions(XA\%), sum of $\mathrm{XA} \%$ in $\mathrm{W}$ and $\mathrm{D}(\mathrm{WDA} \%)$, popular answers (P), active movement (a), passive movement $(\mathrm{p})$, distorted shape $(\mathrm{X}-\%)$, unusual shape $(\mathrm{Xu} \%)$, distorted shape with the inclusion of white space (S-\%), human movement with distorted quality of the shape (M-), index of intellectualization [2AB+(Art+Ay], perseveration answers (PSV), vague answers (DQv), morbid content (MOR), critical special codes (Sum6), weighted sum of critical special codes (WSum6), described in the hypothesis of this study and presented in Table 2.

Some ZSC variables suggest skills and difficulties in social interactions. Suggestions for social interactions are: $\mathrm{H}$, Sum $\mathrm{H},(\mathrm{H})$ which indicate more realistic perceptions of self and others; GHR and COP signify friendlier and collaborative relationships; $\mathrm{W}$ and $\mathrm{D}$ imply the skill to perceive the most important aspects of the situation; XA\% and $\mathrm{X}+\%, \mathrm{WDA} \%$ and $\mathrm{P}$ demonstrate the potential to perceive the facts according to reality and objectively; DQ + and $\mathrm{Zf}$ represent the cognitive effort to analyze the problems; $\mathrm{R}, \mathrm{M}$, and a imply resources to use one's own experience to solve problems, and may favor empathy; Cg informs about the skill to use defenses for protection and caution, which can assist in conflict resolution.

The ZSC variables that demonstrate difficulties or limitations in social interactions are: Sum $\mathrm{T}$ and $\mathrm{Fd}$, represent affective deprivation and dependence; PHR and AG suggest more hostile and conflicted social gatherings; $\mathrm{Xu} \%, \mathrm{X}-\%, \mathrm{~S}-\%$ and $\mathrm{M}$ - indicate singular and unrealistic perceptions of self and others; p, [2AB + (Art + Ay] and isolation reveal a tendency towards more passive, contemplative and social withdrawal behaviors, MOR and An indicate perception of themselves and of the object as damaged, and somatic concerns, $\mathrm{A} \%$, may suggest associative poverty, PSV and DQv, Sum6, WSum6, denote cognitive or thinking difficulties. The variable PER can indicate impairments in social relations, since it refers to more defensive and authoritarian attitudes to justify selfimage. However, because the elderlies often add personal experiences as an attempt to reduce distress and improve relationships (Charles, 2005; Cully et al., 2001), in this context, PER may suggest an inclination to approach and relationship with an affective partner.

The Social Skills Inventory for the Elderly (IHSI - DelPrette). It is the version of the Social Skills Inventory-IHS (Del Prette \& Del Prette, 2001) with small semantic and content adaptations (Carneiro et al., 2007), based on the theoretical model of social skills psychology (Del Prette \& Del Prette, 2001, 2013). After the exploratory and confirmatory factorial analysis performed with a database of 616 elderly patients, a satisfactory internal consistency factor structure (Cronbach's $\alpha=0.926$ ) was obtained and the sample was composed of 20 items organized in 4 factors (Braz, 2013). As in the interpretation of the results of the IHS - Del Prette and IHSA - Del Prette, in the IHSI - Del Prette, the 4 factors are denominated in behavioral terms, considering the situational specificity of social skills, namely:

Factor 1 - Emotional expressiveness ( 7 items, $\alpha=0.885$ ). It addresses the expression of positive or negative feelings: praising family skills, thanking compliments, dealing with fair criticism;

Factor 2 - Assertiveness of confrontation (4 items, $\alpha=0.782$ ). It contemplates the confrontation and selfassertion that present some risk of negative reaction of the interlocutor: to disagree with authority, to interrupt the speech of another, to deal with unjust criticism;

Factor 3 - Conversation and social entrepreneurship (6 items, $\alpha=0.857$ ). It relates to the regulation of verbal communication: engaging in conversation, responding to praise, ending the conversation, interrupting conversation, addressing and initiating conversation with unfamiliar people;

Factor 4 - Sexual affective self-exposure (3 items, $\alpha=0.692)$. It refers to the approach and relationship with affective partner, with or without sexual interest: the ability to introduce oneself to others, to approach for sexual intercourse and to declare a loving feeling.

In the general score, a percentile below 25 is considered: indication for training in social skills; percentile between 25 and 50: good repertoire of social skill; percentile between 50 and 75: good repertoire of social skill (above median); percentile above 75: Elaborate repertoire.

\section{Procedure}

Data collection. After obtaining the letter of authorization from the institutions and approval of the project by the Research Ethics Committee, the data collection was started. Participants sent by the coordinators of the coexistence groups, signed the Term of Free and Informed Consent. The instruments were answered individually, in the dependencies of the elderly cohabitation centers. Initially, the socio-demographic and health characterization protocol and the MSME were administered to verify the inclusion/exclusion criteria. Those who were eligible for the study answered the ZSC and then the IHSI in an hour and a half. For a better reliability of the findings, $25 \%$ of the ZSC protocols were drawn and sent to recode an independent judge, after which the Kappa coefficient analysis was carried out. Values of 0.62 to 0.98 were obtained for all test variables. Such a coefficient of accuracy reveals high reliability (Landis \& Koch, 1977).

Data analysis. The normal distribution of the data was assessed by the visual analysis of the variables distribution histograms and the Kolmogorov-Smirnov test. The associations of the relationship variables and the cognitive triad of the ZSC with the factors of the IHSI Del-Prette, were conducted using the Pearson correlation, with a probability value $\leq 0.05$. 


\section{Ethical Considerations}

The study was approved by the Research Ethics Committee of the University of Passo Fundo, under opinion No. 042/2013.

\section{Results}

In the description of the results the data of the associations of the ZSC with the IHSI Del-Prette are presented. The correlations of the relationship variables [SumT, Fd, H pure, Sum H, Hd, (H), (Hd), GHR and PHR, GPHR, a, p, isolation, PER, AG, COP] and the animal content (A\%), anatomy (An) and clothing $(\mathrm{Cg})$ of the ZSC, with the IHSI Del-Prette factors, can be visualized in Table 1 .
As can be seen in Table 1, there were statistically significant, low magnitude associations of the PER, $\mathrm{Cg}$ and $\mathrm{A} \%$ answers of the ZSC with the general IHSI score and factors. The PER variable demonstrated a significant and positive association with F4, suggesting that personalized answers increase as the skill to sexual affective self-exposure is shown to be higher.

The variable $\mathrm{Cg}$ denoted a significant and positive association with F2, indicating that the answers that refer to the clothing content increase as the confrontation assertiveness skill is shown to be higher. There was a significant and negative association between $\mathrm{A} \%$ content and $\mathrm{F} 3$ content, suggesting that the frequency of animal content answers diminishes when the skill conversation and social develop increases. Table 2 presents the correlations of the cognitive triad variables: information processing (R, PSV, DQv, DQ+, a, Zf, M, W); mediation (X-\%, Xu\%, X+\%, XA\%, WDA\%, P, D, Dd, S-); ideation (MOR, M, a, p, [2AB+(Art+Ay)], Sum6, WSum6, M-) of the ZSC with the IHSI.

Table 1

Person Correlation of ZSC interpersonal relationship variables with IHSI

\begin{tabular}{|c|c|c|c|c|c|c|c|}
\hline \multirow{2}{*}{$\begin{array}{l}\text { Zulliger } \\
N 78\end{array}$} & \multirow[b]{2}{*}{$M$} & \multirow[b]{2}{*}{$S D$} & \multirow{2}{*}{$\begin{array}{c}\text { G1 } \\
r\end{array}$} & \multirow{2}{*}{$\begin{array}{c}\mathrm{F} 1 \\
r\end{array}$} & \multirow{2}{*}{$\begin{array}{c}\mathrm{F} 2 \\
r\end{array}$} & \multirow{2}{*}{$\begin{array}{c}\text { F3 } \\
r\end{array}$} & \multirow{2}{*}{$\begin{array}{c}\text { F4 } \\
r\end{array}$} \\
\hline & & & & & & & \\
\hline Sum H & 1.90 & 1.55 & 0.193 & 0.165 & 0.193 & 0.012 & 0.118 \\
\hline Pure H & 0.85 & 1.03 & 0.069 & 0.043 & 0.130 & 0.065 & 0.057 \\
\hline$(\mathrm{H})$ & 0.58 & 0.74 & 0.175 & 0.191 & 0.122 & 0.072 & 0.064 \\
\hline $\mathrm{Hd}$ & 0.43 & 0.74 & 0.150 & 0.137 & 0.097 & 0.138 & -0.092 \\
\hline$(\mathrm{Hd})$ & 0.05 & 0.22 & 0.214 & 0.088 & 0.202 & 0.112 & 0.176 \\
\hline GHR & 1.06 & 0.93 & 0.079 & 0.096 & 0.040 & 0.058 & 0.039 \\
\hline PHR & 1.12 & 0.95 & 0.217 & 0.211 & 0.205 & 0.036 & 0.072 \\
\hline COP & 0.23 & 0.45 & 0.051 & 0.001 & 0.043 & 0.116 & -0.042 \\
\hline Sum T & 0.58 & 0.76 & -0.010 & -0.122 & 0.095 & -0.008 & -0.031 \\
\hline $\mathrm{Fd}$ & 0.18 & 0.42 & -0.089 & -0.071 & -0.067 & -0.026 & -0.115 \\
\hline PER & 0.78 & 1.22 & 0.145 & 0.068 & 0.111 & 0.042 & $0.236^{*}$ \\
\hline Isolation & 1.73 & 1.52 & 0.051 & 0.213 & -0.101 & -0.045 & 0.118 \\
\hline AG & 0.45 & 0.63 & 0.034 & 0.107 & 0.085 & -0.067 & -0.026 \\
\hline $\mathrm{A} \%$ & 54.84 & 22.76 & 0.076 & 0.151 & 0.161 & $-0.223^{*}$ & 0.152 \\
\hline $\mathrm{Cg}$ & 0.36 & 0.63 & 0.163 & 0.052 & $0.249 *$ & 0.004 & 0.151 \\
\hline An & 0.38 & 0.69 & 0.139 & 0.065 & 0.140 & 0.096 & 0.102 \\
\hline
\end{tabular}

Note. Legend of ZSC variables: Sum $\mathrm{H}=$ amount of human answers; Pure $\mathrm{H}=$ whole human; $(\mathrm{H})=$ whole para-human; $\mathrm{Hd}=$ partial human; $(\mathrm{Hd})=$ partial para-human; $\mathrm{GHR}=$ good representations; $\mathrm{PHR}=$ poor human representations; $\mathrm{PER}=$ personalized answers; $\mathrm{COP}=$ cooperative movement; Sum T = number of texture answers; Fd = food, PER - personalized answers; $A G=$ aggressive movement; $\mathrm{A} \%=$ animal content; $\mathrm{Cg}=$ clothing; $\mathrm{An}=$ anatomy. ${ }^{*} p \leq 0.05$.

Table 2 shows statistically significant, low magnitude associations of $\mathrm{R}, \mathrm{D}, \mathrm{XA} \%, \mathrm{~S}-, \mathrm{X}+\%$ of the $\mathrm{ZSC}$ with the IHSI Del-Prette. The variable $\mathrm{R}$ showed significant associations in a positive and low way with G1, F1 and
F4, suggesting that the number of answers increases as social skills in general increase, and especially those that refer to emotional expressiveness and sexual affective selfexposure. 
Table 2

Person Correlation of ZSC cognitive triad variables with IHSI

\begin{tabular}{|c|c|c|c|c|c|c|c|}
\hline \multirow{2}{*}{$\begin{array}{l}\text { Zulliger } \\
N 78\end{array}$} & \multirow[b]{2}{*}{$M$} & \multirow[b]{2}{*}{$S D$} & \multirow{2}{*}{$\begin{array}{c}\text { G1 } \\
r\end{array}$} & \multirow{2}{*}{$\begin{array}{c}\mathrm{F} 1 \\
r \\
\end{array}$} & \multirow{2}{*}{$\begin{array}{c}\mathrm{F} 2 \\
r\end{array}$} & \multirow{2}{*}{$\begin{array}{c}\text { F3 } \\
r\end{array}$} & \multirow{2}{*}{$\begin{array}{c}\mathrm{F} 4 \\
r\end{array}$} \\
\hline & & & & & & & \\
\hline $\mathrm{R}$ & 8.78 & 3.74 & $0.221^{*}$ & $0.249 *$ & 0.206 & -0.103 & $0.261^{*}$ \\
\hline $\mathrm{ZF}$ & 3.71 & 2.02 & 0.151 & 0.049 & 0.147 & 0.118 & 0.101 \\
\hline W & 1.46 & 1.01 & -0.078 & -0.199 & 0.010 & 0.110 & -0.127 \\
\hline $\mathrm{D}$ & 5.94 & 2.28 & 0.139 & $0.264 *$ & 0.028 & -0.070 & 0.202 \\
\hline Dd & 1.36 & 2.43 & 0.135 & 0.201 & 0.163 & -0.190 & 0.213 \\
\hline $\mathrm{M}$ & 0.71 & 0.99 & 0.055 & 0.035 & 0.065 & 0.081 & 0.088 \\
\hline PSV & 0.31 & 0.54 & 0.005 & -0.120 & 0.009 & 0.125 & -0.002 \\
\hline DQV & 0.49 & 0.80 & -0.083 & -0.078 & -0.104 & 0.017 & -0.066 \\
\hline $\mathrm{DQ}^{+}$ & 2.00 & 1.47 & 0.183 & 0.079 & 0.181 & 0.101 & 0.145 \\
\hline XA\% & 76.57 & 14.74 & -0.135 & -0.033 & $-0.326^{*}$ & 0.060 & -0.123 \\
\hline WDA $\%$ & 71.63 & 17.76 & -0.150 & -0.089 & -0.204 & 0.089 & -0.154 \\
\hline $\mathrm{Xu} \%$ & 27.79 & 16.95 & 0.212 & 0.128 & 0.110 & 0.175 & 0.087 \\
\hline X-\% & 21.75 & 14.02 & 0.123 & 0.069 & 0.187 & -0.078 & 0.110 \\
\hline S- & 0.41 & 0.57 & 0.056 & 0.155 & 0.080 & $-0.247^{*}$ & $0.228^{*}$ \\
\hline $\mathrm{X}+\%$ & 48.91 & 21.18 & $-0.269 *$ & -0.122 & $-0.287^{*}$ & 0.063 & -0.157 \\
\hline $\mathrm{P}$ & 1.08 & 0.88 & -0.028 & -0.098 & 0.099 & -0.013 & -0.100 \\
\hline $\mathrm{a}$ & 1.7 & 1.11 & 0.128 & 0.119 & 0.116 & 0.106 & -0.030 \\
\hline $\mathrm{p}$ & 0.97 & 1.13 & -0.001 & 0.006 & -0.004 & 0.004 & -0.022 \\
\hline M- & 0.06 & 0.25 & 0.044 & -0.028 & 0.047 & -0.036 & 0.147 \\
\hline MOR & 0.23 & 0.45 & 0.029 & -0.301 & -0.069 & 0.137 & 0.780 \\
\hline $2 \mathrm{AB}+(\mathrm{Art}+\mathrm{Ay})$ & 1.32 & 1.46 & 0.017 & -0.009 & -0.019 & 0.097 & -0.053 \\
\hline Sum 6 & 0.54 & 0.65 & 0.026 & -0.087 & -0.30 & 0.182 & -0.025 \\
\hline Wsum6 & 1.46 & 2.24 & 0.137 & -0.041 & 0.088 & 0.191 & 0.074 \\
\hline
\end{tabular}

Note. Legend of ZSC variables: $\mathrm{R}=$ amount of answers; $\mathrm{ZF}=$ organizational activity; $\mathrm{W}=$ whole answers; $\mathrm{D}=\mathrm{detail}$ answer; $\mathrm{Dd}=\mathrm{Unusual}$ detail; $\mathrm{M}=$ human movement; PSV = perseverance answers; DQv = vague answers; $\mathrm{DQ}+=$ answer synthesized; XA $\%=$ appropriate shape with minimum distortions; WDA $\%=$ sum of $\mathrm{XA} \%$ in $\mathrm{W}$ and $\mathrm{D} ; \mathrm{Xu} \%=$ unusual shape; $\mathrm{X}-\%=$ distorted shape; $\mathrm{S}-=$ distorted shape with the inclusion of white space; $\mathrm{X}+\%=$ conventional shape; $\mathrm{P}=$ popular answers; $\mathrm{a}=$ active movemen; $\mathrm{p}=$ passive; $\mathrm{M}-=$ human movement with distorted quality of the shape; $\mathrm{MOR}=$ morbid content; $[2 \mathrm{AB}+($ Art $+\mathrm{Ay})]=$ index of intellectualization; Sum $=$ critical special codes; WSum $6=$ weighted sum of critical special codes. * $p \leq 0.05$.

Variable D showed, significantly, a positive and low association with F1, suggesting that the usual detail answers increase when emotional expressiveness presents with higher scores. The S-variable exhibited a significant and negative association with F3 and positive with F4, suggesting that white space answers with distorted shape decrease as the skill of social conversation and develop increases, and Sincreases when affective self-exposition shows higher scores.

The variables $\mathrm{XA} \%$ and $\mathrm{X}+\%$ showed a significant negative and low correlation with F2 signaling that adequately and conventionally the answers diminish as the confrontation assertiveness skill increases. Significant association of negative form of $\mathrm{X}+\%$ with $\mathrm{G} 1$ was observed, suggesting that the conventional answers are associated to the decrease of social skills.

The variables that inform about limitation in interpersonal relationship and cognitive problems (PHR, AG, Fd, Sum T,
Isolation, $\mathrm{An}, \mathrm{Dd}, \mathrm{X}-\%, \mathrm{Xu} \%, \mathrm{M}-, 2 \mathrm{AB}+\mathrm{Art}+\mathrm{Ay}, \mathrm{p}, \mathrm{PSV}$, DQv, MOR, Sum6 and WSum6) did not denote association with the general G score and IHSI Del-Prette factors (F1, F2, F3, F4). Other variables that indicate competence in interpersonal relationship and cognitive adjustment (Sum $\mathrm{H}, \mathrm{H},(\mathrm{H}), \mathrm{GHR}$ and COP, ZF, M and DQ +) also had no significant association with the general $\mathrm{G}$ score and IHSI Del-Prette factors (F1, F2, F3, F4).

\section{Discussion}

Upon reaching the proposed goal, this study brought evidence of convergent validity of the relationship indicators and the cognitive triad of the ZSC with the self-reported social skills of the IHSI Del-Prette. Among the main results are: (i) the PER, $\mathrm{Cg}, \mathrm{A} \%$ answers of the ZSC, which report 
on aspects of interpersonal relationships (defenses, concerns and interests), showed significant correlations with F4, F2 and F3 of the IHSI, respectively; (ii) the variables R, D, $\mathrm{XA} \%, \mathrm{~S}-, \mathrm{X}+\%$ of the ZSC that report on cognitive aspects (processing, mediation and ideation) were associated with G1, F1, F4, F3 and F2 respectively of the IHSI Del- Prette.

In this study, the elderly who presented greater authoritarianism in approaching people or confrontation with situations in ZSC (PER), were more skilled in sexual affective self-exposure (F4). This result may be due to the need to justify defensively their self-image (Exner \& Sendín, 1999), whether to declare love or sexual feelings (Z. A. P. Del Prete \& A. Del Prete, 2001).

The increase of the PER variable in non-patient elderly was reported in another study (Pertchik et al., 2007) as well as the positive association between PER and self-exposure to unknown and new situations in IHS (F4) in adults (Grazziotin \& Scortegagna, 2012, 2013). In agreement with researchers of the psychology of the aging, the authors understand that the increase in the number of personal associations between past and present experiences of the life, in older adults, can take them to the complex understanding of situations and seems to have no narcissistic connotation (Charles, 2005). Along with this, the tendency to add personal associations to late-life conversations is described as a normative reminiscence process that can improve relational quality (Cully et al., 2001).

In a more recent study, Meyer et al. (2015) found significant associations between age and three R-PAS variables: Vigilance Compound (V-Comp), ShadingTexture Determinant (T) and Personal Knowledge Thematic Code (PER). The authors conclude that the limited number of elderly people who compose the sample reduces the likelihood of detecting potential effects of aging and drives the need for further investigation to examine possible declines in complexity variables related to advancing age.

Rien et al. (2017), observed a decrease in PER in elderly people with Parkinson's disease, who made up a clinical group, compared to those free of disease that were part of the non-clinical group. The authors understood that due to the need for more care and assistance, as the disease progresses, there are more functional limitations of all kinds, the elderly in the clinical group tend to be less imposing and more passive.

Retrieving other findings from the present study, older people who exhibited more use of defenses aimed at protection, caution and identity disclosure $(\mathrm{Cg})$ (Weiner, 2003), demonstrated greater confrontation assertiveness (F2), where it is necessary to disagree of authority, to deal with unjust criticism (Braz et al., 2011). This result suggests two aspects: First, that the elderly tend not to show their true thoughts and feelings directly, when they face situations with some risk of negative reaction of the interlocutor. The second is that the elderly need to express their desires, needs and singularities. This is because, the type of dress or accessory named may be representing a defense (helmet, raincoat), revealing an identity (collar, dress), or both (Exner \& Sendín, 1999; Weiner, 2003).
This protection and prevention behavior in the elderly may represent: (i) defenses arising from the fear of not being estimated, from approaching death and from avoiding confrontation in a society that does not value them very much (Cully et al. , 2001); (2) the desire for social inclusion and the diffusion of their life experiences (Braz et al., 2013, Scheibe \& Carstensen, 2010, WHO, 2015), which should be better investigated in future studies.

The greater disposition for behaviors with less associative wealth $(\mathrm{A} \%)$ was evidenced in those that demonstrated greater restriction in the capacity for social communication skill (F3). In the elderly, these results are especially important, since there is a higher incidence of chronic diseases; the loss of partners and loved ones may be more frequent (WHO, 2015), and thus limit social participation and interest in news. Nevertheless, because they have extensive life experience, the elderly can transmit values and teachings to future generations (Braz et al., 2013). Considering this potential, the development of interpersonal communication provides quality in the relationships and potentiates the resources of the elderly, in expressions of affection, care, in conflict resolution (Braz et al., 2013; Carneiro et al., 2007).

The productive, motivational, cooperative and intellectual capacity (R) (Exner \& Sendín, 1999; Villemor-Amaral \& Primi, 2012) in the elderly has been shown to be related to a more developed social skills repertoire (G1), especially in expressiveness of positive or negative feelings (F1) and in the establishment of affective and sexual relationships (F4). Previous studies indicate that motivated, affective and collaborative people usually have good productivity in the ZSC (Grazziotin \& Scortegagna, 2012, 2013). The confrontation of stress and the control of negative emotions (Pinto et al., 2016), the social interaction and the academic performance (Bolsoni-Silva \& Loureiro, 2014; Feitosa et al., 2012) are also reported in adults with higher social skills scores. In the study by Gregoleti and Scortegagna (2017), elderly patients with chronic kidney disease when compared to those free of disease, presented a decrease in $\mathrm{R}$, which for the authors may derive from deprivation of leisure and interests, and employment restrictions.

The elderly who indicated more economic and practical characteristics (D), also showed greater emotional expressiveness, which relates to, for example, dealing with unjust criticism and positive and negative feelings, presents with higher scores. Among older people, these findings may reflect the idea that many of them perceive that lifespan to achieve some goals is shorter, and therefore seem to express their feelings more intensely and set shorter and more practical goals for problem solving, which may helping to increase feelings of achievement and well-being (Scheibe \& Carstensen, 2010; WHO, 2015).

In this study, elevated anxiety, misperceptions about reality, and negative affects such as anger (S-) have shown to move in the opposite direction of skills such as conversational and social develop (F3). However, these negative affections with distorted thoughts were also increased in elderlies with greater sexual affective self-exposure (F4). This data 
shows the possible breakdown of barriers and patterns preestablished by the elderlies, when affections and sexuality are displayed more directly. On these occasions and because of social stigmas, there may be increased anxiety, resentment and distorted perception of reality. This is because it is often assumed that advanced age implies only passivity, dependence. However, there is evidence that people of more advanced ages are changing this rigid framework, seeking to enjoy a new career, promulgating their experiences or reinvesting in love relationships (WHO, 2015).

The results confirm the hypothesis of this study, that the more adjusted the people in their relationships and the cognitive level, the greater the repertoire of social skills. Elderly individuals who showed higher productivity (R) and objectivity (D) in the ZSC were more likely to express positive or negative feelings (F1) and more social skills generally in the IHS-Del Prette $(\mathrm{G})$. Those that denote a greater limitation in the production of ideas $(\mathrm{A} \%)$ and, when they have negative affections, tend to distort reality (S-) showing less skill of social develop. The use of defensive and protective measures (PER and $\mathrm{Cg}$ ) in relation to weaknesses and insecurities in relationships was shown to be increased in the elderly with more disposition to self-affirming behaviors and sexual affective self-exposure, respectively.

If, on the one hand, the hypotheses of this study were confirmed, on the other hand it is verified that the more traditional (XA\%), more conventional and mainly more rigid $(\mathrm{X}+\%)$, countered social skills (G1), especially that of assertiveness of confrontation (F2), not confirming one of the hypotheses of this study. In agreement with the literature (WHO, 2015), the authors understand that older people, mainly from Western cultures, due to feelings of fear, despair and insecurity may depart from the conventional, pre-set and judged standards, to meet their rights, desires and opportunities. Allied to this, to adapt to the declines due to the more advanced age, the elderlies often make a shift from negative to positive emotions, which can give them emotions of optimism and well-being, but can also make them more vulnerable to making mistakes (Scheibe \& Carstensen, 2010).

For the lack of correlation between ZSC variables (Sum $\mathrm{H}, \mathrm{H},(\mathrm{H})$, GHR and COP ZF, M e DQ+, PHR, AG, Fd, Sum T, Isolation, An, Dd, X-\%, Xu\%, M-, 2AB+Art+Ay, p, PSV, DQv, MOR, Sum6 and WSum6) with the IHSI (score G and F1, F2, F3, and F4), it should be considered that there may be small associations between introspective characteristics (self-reported) and behaviors (Mihura, 2012), in addition to the intrinsic differences of each instrument that can intervene in this result. Some discrepancies exist between what people say about themselves and how they act. Therefore, it is feasible to combine different methods in the evaluations, especially the use of instruments that allow indirect access to the psychic universe (Dao et al., 2008; Mihura, 2012).

As can be verified, the results found in this study met the proposed objective and evidenced indicators of convergent validity of interpersonal relationship variables and the cognitive triad of the ZSC with the IHSI Del-Prette. It is possible to reaffirm the relevance of the two instruments in the psychological evaluation, since besides the results corroborate the hypotheses listed, they provided important subsidies for the psychic understanding of the elderly. However, it should be mentioned that these findings are based on a restricted sample and cannot be generalized for all the elderly, but the follow up of studies, especially with this emerging population and the inclusion of other ZSC variables, in different contexts, may favor this generalization. New research could verify the differences between groups of older people, with more social skills and with fewer social skills, and analyze partial correlations controlling the effect of age and schooling.

\section{References}

American Educational Research Association, American Psychological Association, Nacional Council on Measurement in Education. (2014). Standards for educational and psychological testing. Washington, DC: American Educational Research Association.

Associação Brasileira de Empresas de Pesquisa. (2012). Critério de Classificação Econômica Brasil. Retrieved from http://www.abep.org/criterio-brasil

Bertolucci, P. H. F., Brucki, S. M. D., Campacci, S. R., \& Juliano, Y. (1994). O mini-exame do estado mental em uma população geral: Impacto da escolaridade [The MiniMental State Examination in an outpatient population: Influence of literacy]. Arquivos de Neuro-Psiquiatria, 52(1), 1-7. doi:10.1590/S0004-282X1994000100001

Bolsoni-Silva, A. T., \& Loureiro, S. R. (2014). The role of social skills in social anxiety of university students. Paidéia (Ribeirão Preto), 24(58), 223-232. doi:10.1590/1982-43272458201410

Braz, A. C. (2013). Habilidades sociais e solidariedade intergeracional no relacionamento entre pais idosos e filhos adultos [Social skills and intergenerational solidarity older parent and adultchildren relationship] (Doctoral dissertation). Retrieved from https://repositorio.ufscar.br/bitstream/ handle/ufscar/5989/5777.pdf?sequence=1\&isAllowed=yZ

Braz, A. C., Cômodo, C. N., Del Prette, Z. A. P., Del Prette, A., \& Fontaine, A. M. G. (2013). Habilidades sociales e intergeneracionalidad en las relaciones familiares [Social skills and intergenerational family relationships]. Apuntes de Psicología, 31(1), 77-84. Retrieved from http:// www.apuntesdepsicologia.es/index.php/revista/article/ view/305/285

Braz, A. C., Del Prette, Z. A. P., \& Del Prette, A. (2011). Assertive social skills training for the elderly. Behavioral Psychology /Psicología Conductual, 19(2), 373-387. Retrieved from https://www.researchgate.net/publication/222093501_ Assertive_social_skills_training_for_the_elderly

Brucki, S. M. D., Nitrini, R., Caramelli, P., Bertolucci, P. H. F., \& Okamoto, I. H. (2003). Sugestões para o uso do Mini-Exame do Estado Mental no Brasil [Suggestions for utilization of the mini-mental state examination in Brazil]. Arquivos de Neuro-Psiquiatria, 61(3-B), 777-781. doi:10.1590/S0004-282X2003000500014 
Carneiro, R. S., Falcone, E., Clark, C., Del Prette, Z., \& Del Prette, A. (2007). Qualidade de vida, apoio social e depressão em idosos: Relação com habilidades sociais [Quality of life, social support and depression of the elderly: Relationship with social Abilities]. Psicologia: Reflexão e Crítica, 20(2), 229-237. doi:10.1590/S0102-79722007000200008

Charles, S. T. (2005). Viewing injustice: Greater emotion heterogeneity with age. Psychology and Aging, 20(1), 159-164. doi:10.1037/0882-7974.20.1.159

Cully, J.A., LaVoie, D., \& Gfeller, J. D. (2001). Reminiscence, personality, and psychological functioning in older adults. The Gerontologist, 41(1), 89-95. Retrieved from doi:10.1093/geront/41.1.89

Dao, T. K., Prevatt, F., \& Horne, H. L. (2008). Differentiating psychotic patients from nonpsychotic patients with the MMPI-2 and Rorschach. Journal of Assessment, 90(1), 93-101. doi:10.1080/00223890701693819

Del Prette, Z. A. P., \& Del Prette, A. (2001). Inventário de Habilidades Sociais (IHS - Del- Prette): Manual de aplicação, apuração e interpretação [Social Skills Inventory (SSI- Del-Prette): Application manual, calculation and interpretation]. São Paulo, SP: Casa do Psicólogo.

Del Prette, Z. A. P., \& Del Prette, A. (2013). Social Skills Inventory (SSI-Del-Prette): Characteristics and studies in Brazil. In F. Osório (Org.), Social anxiety disorders: From theory to practice (pp. 47-62). New York, NY: Nova Science.

Exner, J., Jr., \& Sendín, C. (1999). Manual de interpretação do Rorschach para o sistema compreensivo [Manual interpretation of the Rorschach comprehensive system] (L. Y. Massuh, Trad.). São Paulo, SP: Casa do Psicólogo.

Feitosa, F. B., Del Prette, Z. A. P., \& Del Prette, A. (2012). Social skills and academic achievement: The mediating function of cognitive competence. Temas em Psicologia, 20(1), 61-70. Retrieved from http://pepsic.bvsalud.org/ pdf/tp/v20n1/v20n1a06.pdf

Folstein, M. F., Folstein S. E., \& McHugh, P. R. (1975). "Mini-mental state": A practical method for grading the cognitive state off patients for the clinician. Journal of Psychiatric Research, 12(3), 189-198. doi:10.1016/0022-3956(75)90026-6

Franco, R. R. C., Cardoso, L. M., Villemor-Amaral, A. E., \& Primi, R. (2012). Estudos de normatização, precisão e validade [Studies of standardization, accuracy and validity]. In A. E. Villemor-Amaral \& R. Primi (Orgs.), Teste de Zulliger no sistema Compreensivo ZSC: Forma individual [Zulliger test in the comprehensive system ZSC- Individually] (2a ed., pp. 115-130). São Paulo, SP: Casa do Psicólogo.
Franco, R. R. C., \& Villemor-Amaral, A. E. (2009). Validade concorrente entre provas de personalidade: Zulliger-SC e Pfister [Concurrent validity of personality tests: Zulliger CS and Pfister]. Revista Psicologia e Saúde, 1(1), 50-59. doi:10.20435/pssa.v1i1.13

Grazziotin, J. B. D. D., \& Scortegagna, S. A. (2012). Zulliger e habilidade social: Evidências de validade no contexto empresarial [Zulliger and social skills: Validity evidence in business context]. Psicologia: Reflexão e Crítica, 25(1), 69-78. doi:10.1590/S0102-79722012000100009

Grazziotin, J. B. D. D., \& Scortegagna, S. A. (2013). Relacionamento interpessoal, produtividade e habilidades sociais: Um estudo correlacional [Interpersonal relationships, productivity and social skills: A correlational study]. Psico-USF, 18(3), 491-500. doi:10.1590/S1413-82712013000300015

Grazziotin, J. B. D. D., \& Scortegagna, S. A. (2016). Revisão de pesquisas brasileiras sobre o Teste de Zulliger publicadas em artigos [Literature review of Brazilian research about the Zulliger Z Test]. Avaliação Psicológica, 15(2), 227-235. doi:10.15689/ap.2016. 1502.11

Gregoleti, V., \& Scortegagna, S. A. (2017). The Zulliger-CS in elderly on hemodialysis and the relationship between external variables. Paidéia (Ribeirão Preto), 27(66), 43-50. doi:10.1590/1982-43272766201706

Landis, J. R., \& Koch, G. G. (1977). The measurement of observer agreement for categorical data. Biometrics, 33(1), 159-174. doi:10.2307/2529310

Meyer, G. J., Giromini, L., Viglione, D. J., Reese, J. B., \& Mihura, J. L. (2015). The association of gender, ethnicity, age, and education with Rorschach scores. Assessment, 22(1), 46-64. doi:10.1177/1073191114544358

Mihura, J. L. (2012). The necessity of multiple test methods in conducting assessments: The Role of the Rorschach and self-report. Psychological Injury and Law, 5(2), 97-106. doi:10.1007/s12207-012-9132-9

Pertchik, K., Shaffer, T. W., Erdberg, P., \& Margolin, D. I. (2007). Rorschach Comprehensive System data for a sample of 52 older adult nonpatients from the United States. Journal of Personality Assessment, 89(Suppl. 1), S166-S173. doi:10.1080/00223890701583598

Pinto, F. N. F. R., Barham, E. J., \& Del Prette, Z. A. P. (2016). Interpersonal conflicts among family caregivers of the elderly: The importance of social skills. Paidéia (Ribeirão Preto),26(64), 161-170. doi:10.1590/198243272664201605

Rien, M., Scortegagna, S. A., Grazziotin, J. B. D. D., \& Bertolin, T. E. (2017). Validity evidence of the Zulliger-CS in older adults with Parkinson's disease. Estudos de Psicologia (Campinas), 34(4), 560-570. doi:10.1590/1982-02752017000400011 
Scheibe, S., \& Carstensen, L. L. (2010). Emotional aging: Recent findings and future trends. Journal of Gerontology: Psychological Sciences, 65B(2), 135-144. doi:10.1093/geronb/gbp132

Tavella, R. R., \& Villemor-Amaral, A. E. (2014). O teste de Zulliger-SC: Avaliação da criatividade em crianças [The Zulliger-SC test: Assessment of children's creativity]. Estudos de Psicologia (Campinas), 31(4), 489-497. doi:10.159/0103-166X2014000400003

Villemor-Amaral, A. E., \& Primi, R. (2012). Teste de Zulliger no Sistema Compreensivo ZSC: Forma individual [Zulliger test in the comprehensive system ZSCIndividually] (2a ed.). São Paulo, SP: Casa do Psicólogo.

Weiner, I. B. (2003). Principles of Rorschach interpretation. Mahwah, NJ: Lawrence Erlbaum.

World Health Organization. (2015). World report on ageing and health. Geneva, Switzerland: Author. Retrieved from http://apps.who.int/iris/bitstream/ handle/10665/186463/9789240694811 eng. pdf;jsessionid=C6DCD 1975DFB6F25B31 CFAB 95220D00A? sequence $=1$

Jucelaine Bier Di Domenico Grazziotin has a master's degree in Human Aging from Universidade de Passo Fundo, Passo Fundo-RS, Brazil.

Silvana Alba Scortegagna is a Full Professor at Universidade de Passo Fundo, Passo Fundo- RS, Brazil.

Authors' Contribution:

All authors made substantial contributions to the conception and design of this study, to data analysis and interpretation, and to the manuscript revision and approval of the final version. All the authors assume public responsability for content of the manuscript.

Received: May. 20, 2016

1st Revision: Oct. 18, 2016

2nd Revision: Mar. 03, 2017

3rd Revision: Apr. 23, 2018

Approved: Apr. 26, 2018

How to cite this article:

Grazziotin, J. B. D. D, Scortegagna, S. A. (2018). Convergent validity of Zulliger-CS with the social skills inventory for the elderly. Paidéia (Ribeirão Preto), 28, e2832. doi: http://dx.doi.org/10.1590/1982-4327e2832 